\title{
Musashi Proteins in Neural Stem/Progenitor Cells
}

\author{
Kenichi Horisawa and Hiroshi Yanagawa \\ Department of Bioscience and Informatics, Keio University \\ Japan
}

\section{Introduction}

Many RNA-binding proteins are encoded in the genomes of various organisms and play a critical role in several life systems. The human genome contains thousands of RNA-binding proteins (Glisovic et al., 2008). The most important biological role for these proteins involves the post-transcriptional events in gene expression, e.g., splicing, export, stabilization, localization, and translation. Recent studies have shown that these post-transcriptional events are of similar importance to transcriptional and post-translational events and are highly orchestrated (Keene et al., 2007).

Musashi is an RNA-binding protein that contains typical RNA-recognition motifs (RRMs). The gene encoding the Musashi protein was originally identified in Drosophila and is responsible for the asymmetrical division of sensory organ precursor cells (Nakamura et al., 1994). Later studies determined that Musashi proteins are RNA-binding proteins that bind to a sequence in the 3'untranslated region (UTR) of tramtrack69 (ttk69) mRNA (Lai \& Li, 1999). The binding of these proteins prevents the translation of ttk69 mRNA, resulting in asymmetric cell division (Hirota et al., 1999; Okabe et al., 2001).

Subsequently, two highly conserved mammalian homolog proteins, Musashi1 (Msi1) and Musashi2 (Msi2), were discovered in mice (Sakakibara et al., 1996, 2001). Over 90 Musashi and Musashi-like proteins have been discovered in various multicellular animals; however, these proteins have not been found in prokaryotes, plants, or monocellular organisms. The expression pattern and structure of these proteins are highly similar among various organisms (Good et al., 1998; Yoda et al., 2000; Kawashima et al., 2000; Cuadrado et al., 2002; Lowe et al., 2003; Asai et al., 2005; Higuchi et al., 2008).

Musashi proteins are highly expressed in the vertebrate nervous system. (Kaneko et al., 2000). In the mammalian central nervous system, Msi1 appears specifically in undifferentiated neural stem/precursor cells during both the embryonic and adult stages (Sakakibara et al., 1996; Kaneko et al., 2000; Sakakibara \& Okano, 1997). Interestingly, Msi1 expression was also observed in many kinds of somatic stem cells in adult tissues, such as the eye (Raji et al., 2007), intestine (Potten et al., 2003), stomach (Akasaka et al., 2005), mammary gland (Clarke et al., 2005), and hair follicles (Sugiyama-Nakagiri et al., 2006).

Later studies revealed that Msi1 maintains the stemness of the neural stem/precursor cells through the translational suppression of $\mathrm{m}-\mathrm{Numb}$, a regulator protein of the Notch signal 
pathway (Imai et al., 2001; Kawahara et al., 2008). Although other target mRNAs of Msi1 have been recently reported, the full function of Msi1 in maintaining stem/precursor cells remains to be elucidated (Battelli et al., 2006; de Sousa Abreu et al., 2009; Horisawa et al., 2009).

Furthermore, the relationship between Musashi proteins and several disease states have recently been reported. Msi1 is reported to play a role in a variety of cancers (Toda et al., 2001; Shu et al., 2002; Sakatni et al., 2005) and neural disorders (Lovell \& Markesbery, 2005; Ziabreva et al., 2006; O'Sullivan et al., 2011; Oki et al., 2010; Nakayama et al., 2010; Crespel et al., 2005).

In this chapter, we present an overview of Musashi proteins, especially mammalian Msi1, and consider possible directions for further research.

\section{The discovery of Musashi proteins and their function}

Musashi was originally identified in a Drosophila mutant with abnormal external sensory organs (Fig.1A\&B). In the early '90s, Nakamura and co-workers showed that the musashi gene is responsible for the asymmetrical division of sensory organ precursor (SOP) cells in Drosophila, which are precursors for the ectodermal system common to both neural and nonneural cell lineages in loss-of-function experiments (Nakamura et al., 1994). In wild-type animals, the SOP cell divides into a non-neural precursor cell (green in Fig.1C) and a neural precursor cell (white in Fig.1C), whereas in musashi mutants, two non-neural precursor cells (white in Fig.1D) are produced instead. The symmetrically divided non-neural precursor cells differentiate to hair-forming cells (Sf and So in Fig.1A\&B), leading to a double-bristle phenotype instead of the single-hair wild-type phenotype (Fig.1 A\&B). Based on this double-hair shape, the gene was named "Musashi" after a famous Japanese swordsman who fought with two swords, Musashi Miyamoto (A.D. 1584-1645).
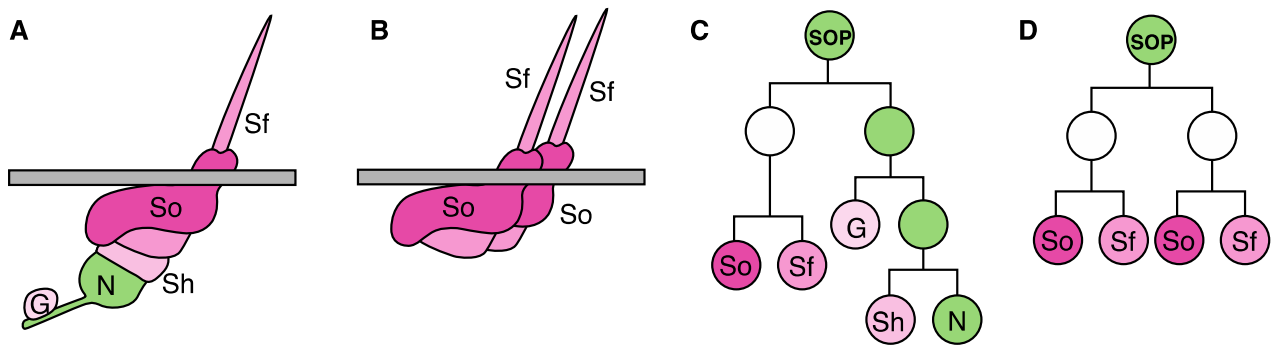

Fig. 1. Structures and cell lineages of the external sensory organs in Drosophila

(A \& B) Structures of the adult external sensory organs (mechanosensory bristles) in wildtype (A) and musahi mutant (B) animals. The cell lineages contain neuron ( $\mathrm{N}$; green) and non-neuronal support cells (magenta), a shaft cell (Sf), a socket cell (So), a sheath cell (Sh) and glia (G); (C \& D) Cell lineages of the mechanosensory bristle in wild-type (C) and musashi mutant (D) animals. Cells with neuronal potential are green, and non-neuronal cells are magenta and white.

Subsequent studies revealed that the Musashi protein, which has RNA-binding activity, introduces neural differentiation potential for one daughter cell of the SOP cell via selective translational repression of the mRNA of a neural differentiation inhibitory factor (a transcription repressor possessing a BTB domain and zinc-finger domain) called ttk69 
(Okabe et al., 2001). The ttk69 protein is located downstream in the Notch signaling pathway and acts as a determinant of non-neural identity.

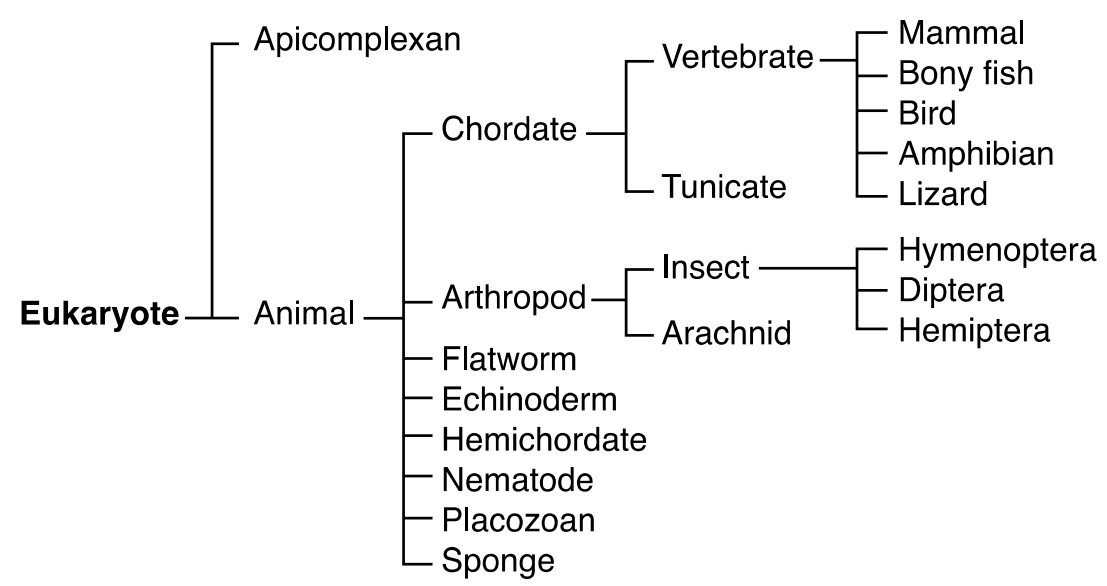

All listed organisms are multi-cellular eukaryotes.

Fig. 2. A dendrogram of the organisms bearing the musashi or musashi-related genes.

The Systematic Evolution of Ligands by EXponential enrichment (SELEX) assay (Tuerk \& Gold, 1990), an in vitro selection method for RNA, was employed to identify the specific target RNA motifs of Musashi proteins from a synthesized random-sequence RNA library. Uridine-rich sequences containing two or three (GUU...UAG) or (GUU...UG) repeats were identified as Musashi binding targets (Okabe et al., 2001). Indeed, ttk69 mRNA contains 15 of these motif sequences in the $3^{\prime} \mathrm{UTR}$, and it has been demonstrated that the Musashi protein binds to the $3^{\prime} \mathrm{UTR}$ of $t$ tk69 mRNA and inhibits the translation of a reporter gene linked to the 3'UTR in vitro (Okabe et al., 2001).

Musashi and Musashi-like proteins have since been discovered in several multicellular organisms, but these genes have not been found in prokaryotes, plants, or monocellular organisms (Fig.2). This implies that the Musashi protein is specifically required for the development and evolution of multicellular animals.

\section{The homologs of Musashi protein in mammals}

Further studies in Drosophila have revealed that the Musashi protein is also expressed in the compound eye primordium (Hirota et al., 1999), CNS (Nakamura et al., 1994), and neural stem/precursor cells in the larval brain (Nakamura et al., 1994), which have many characteristics in common with mammalian neural stem cells (NSCs) (Ito \& Hotta, 1992). Thus, to elucidate the functions of the Musashi gene family in mammals, a homolog search and immunohistochemical studies were performed in mice.

Two highly conserved homolog genes, musashi1 (msi1) (Sakakibara et al., 1996) and musashi2 (msi2) (Sakakibara et al., 2001), were discovered in mice. While the length of these proteins are considerably shorter than that of Drosophila Musashi, the RNA-recognition motifs (RRMs) were highly conserved ( 95\% identical) between mammalian and insect systems (Fig.3). 


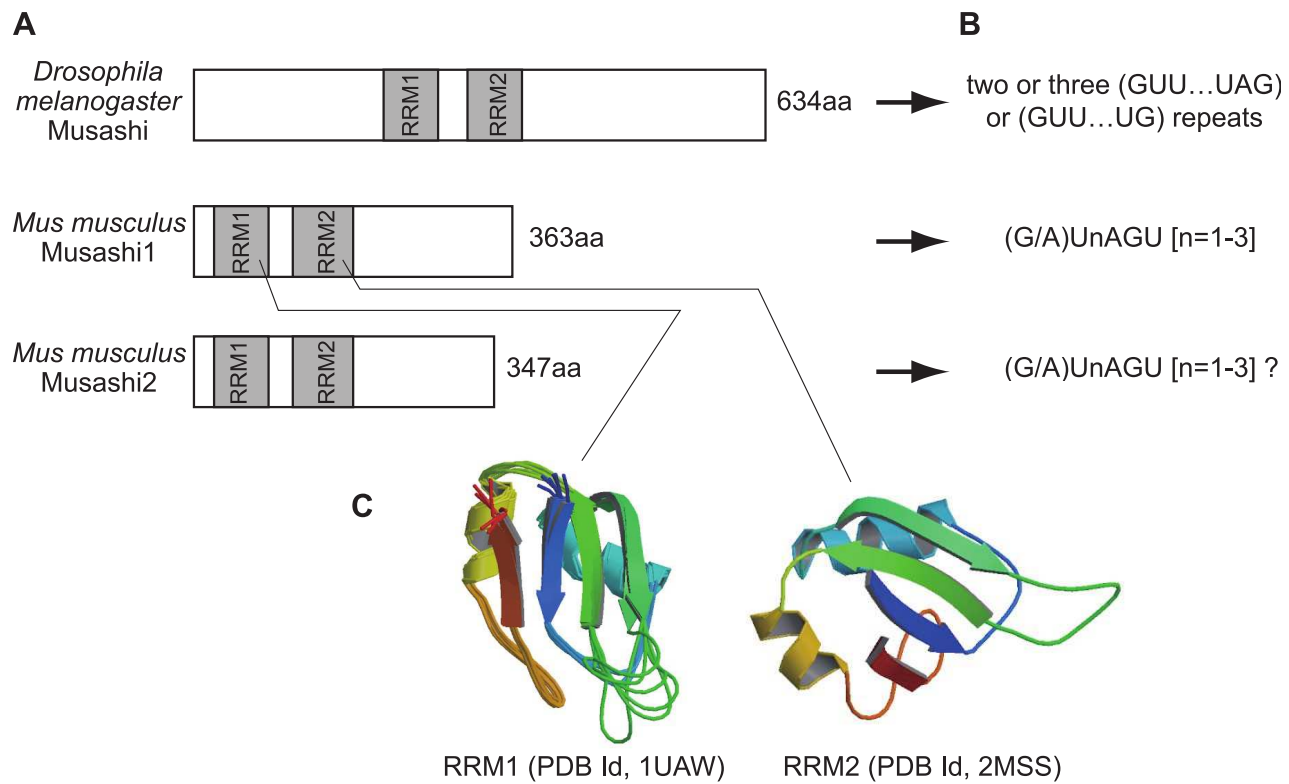

Fig. 3. The structures of Musashi proteins and their target RNA sequences

(A) Primary structures of Musashi proteins in Drosohila melanogaster and Mus musculus.

(B) Musashi binding motifs in target mRNAs. (C) Partial 3D structures of RRMs of Msi1 protein.

A high level of expression of Msi1 in NSCs of the periventricular area and undifferentiated neural precursor cells (Sakakibara et al., 1996; Kaneko et al., 2000; Sakakibara \& Okano, 1997) was observed. Therefore, Msi1 is now widely used as a marker of NSCs and progenitor cells in the CNS of a variety of vertebrates. These cells, which can form neurospheres, were identified in the adult human brain using this approach (Pincus et al., 1998). Precise immunohistochemical analyses revealed that Msi1 is strongly expressed in the ventricular zone of the neural tube in embryos and in neurogenic sites within the postnatal brain, including the subventricular zone (SVZ), olfactory bulb, and rostral migratory stream (RMS) (Sakakibara \& Okano, 1997). The Msi1 protein is expressed in neural stem/progenitor cells within these tissues and is rapidly down-regulated in post-mitotic neurons (Sakakibara et al., 1996).

The Msi2 protein in mice is a paralog of Msi1, displaying more than $90 \%$ homology with the Msi1 protein in the RRMs (Sakakibara et al., 2001) (Fig.3). Although the expression pattern in the CNS is very similar between the members of this family, Msi2 is also continuously expressed in a subset of neuronal lineage cells, such as parvalbumin-containing GABA neurons in the neocortex and neurons in several nuclei of the basal ganglia (Sakakibara et al., 2001). Other reports have also shown a differential expression pattern of these genes in uroepithelial cells (Nikpour et al., 2010). Although the functional properties (e.g., RNAbinding specificity) of the two proteins are similar, these differences in expression might explain the functional assignation of these proteins. 
Although the partial 3D structures of RRMs of Msi1 protein have been solved by NMR, the full-length 3D structures of Msi1 and Msi2 remain to be elucidated (Nagata et al, 1999; Miyanoiri et al, 2003).

The human genome also contains both $m s i 1$ and msi2 genes (Good et al., 1998; Sakakibara et al., 2001). The structure and expression pattern of these proteins in the CNS highly resemble those in mice. As described below, Musashi proteins are related to several diseases. Functional studies in mice will thus contribute to therapeutic developments for Musashirelated conditions.

Additionally, a small Msi2-like gene, LOC100504473, has been found near the Msi2 locus on the mouse genome, but its expression and function are yet to be defined.

\section{Molecular and physiological functions of Musashi proteins in stem/progenitor cells}

To identify the target RNAs of Msi1 in mammals, a SELEX analysis from a randomsequence RNA library was performed, similar to those done in Drosophila. The selected consensus sequence revealed that the mouse Msi1 protein binds specifically to RNAs that possess a (G/A)UnAGU [n=1-3] sequence (Imai et al., 2001) (Fig.3).

A survey for the motif was performed in mRNAs expressed in the embryonic CNS. The 3'UTR region of m-numb mRNA (Zhong et al., 1996) was highlighted as a candidate target. Subsequent experiments found that m-munb mRNA is a specific binding target of the Msi1 protein in vitro and in vivo. Its translation is repressed by the Msi1 protein (Imai et al., 2001; Kawahara et al., 2008).

The m-Numb protein binds to the intracellular domain of the Notch protein, which has nuclear translocation and transactivation activities, and inhibits the Notch signaling pathway (Berdnik et al., 2002), which positively regulates neural stem cell self-renewal (Nakamura et al., 2000; Hitoshi et al., 2002; Tokunaga et al., 2004) (Fig.4). In agreement with this hypothesis, oscillation in the expression of the hes1 gene, a downstream target of Notch, controls the differentiation of embryonic stem cells to neural cells (Kobayashi et al., 2009). Indeed, the Msi1 protein induces the expression of the hes1 gene (Imai et al., 2001; Yokota et al., 2004).

Musashi proteins in both mammalian species and Drosophila contribute to maintaining the stem/progenitor cell status via translational repression of target mRNA. However, the target mRNAs are, interestingly, not orthologous. This result implies a highly conserved function of Musashi proteins in maintaining the stemness of progenitor/stem cells and the probable presence of other unknown target RNAs of the Musashi proteins.

Recently, mammalian Msi1 protein expression was identified not only in CNS, but also in other tissues and organs in embryonic or adult stages, including the eye (e.g., corneal epithelium, corneal endothelium, stromal keratocyte, progenitor cell of the limbus, equatorial lens stem cell, differentiated lens fiber, and retinal pigment epithelium cells) (Raji et al., 2007; Susaki et al., 2009), intestine (small intestinal crypt, colon crypt, columnar cell, and epithelial cell) (Kayahara et al., 2003; Nishimura et al., 2003; Potten et al., 2003; Asai et al., 


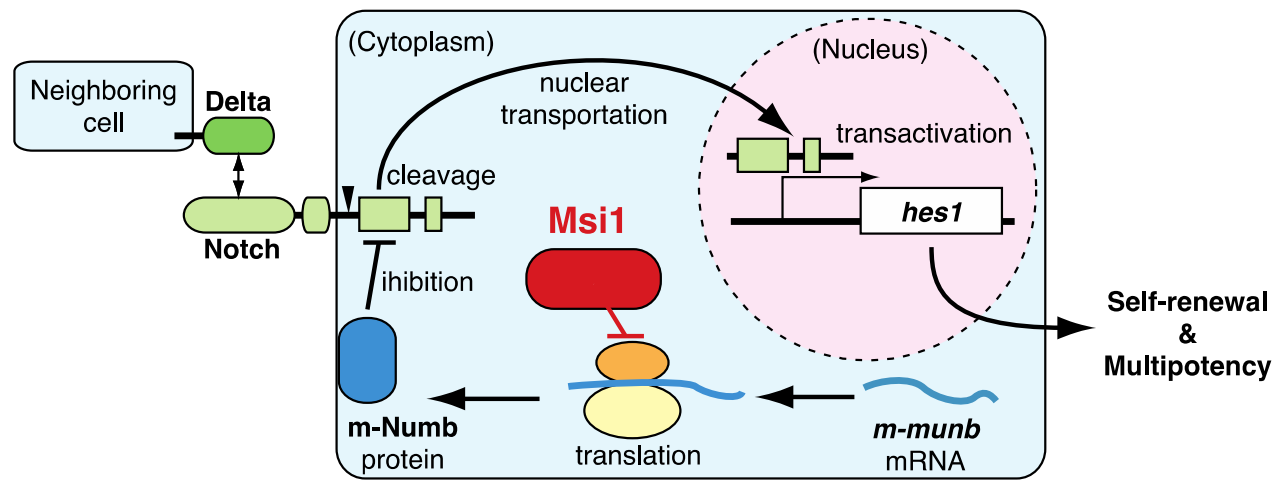

Fig. 4. A model for Msi1 function in the regulation of Notch signaling

Msi1 translationally regulates m-numb gene expression. Because m-Numb blocks the activation of the Notch signal induced by Delta on neighboring cells, translational repression of m-Numb by Msi1 stimulates Notch signaling and HES1 pathways.

A

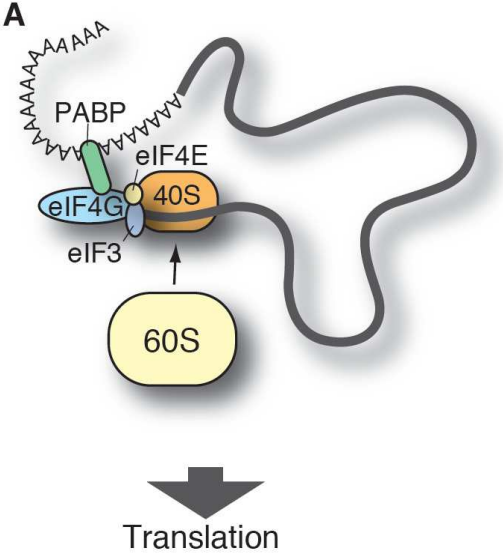

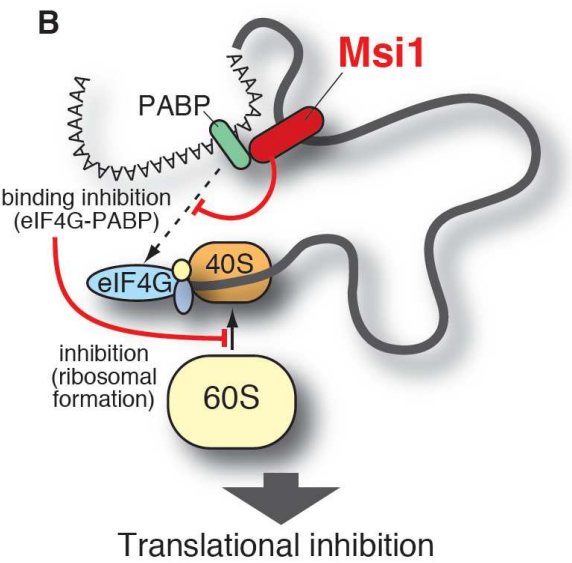

Translational inhibition

Fig. 5. Schematic representation of the molecular function of Msi1

(A) Translation of a non-target mRNA of Msi1; (B) Translational inhibition of a target mRNA of Msi1. The Msi1 protein interacts with the 3'UTR of its target mRNA and PABP and subsequently inhibits translation initiation by competing with eIF4G for PABP. These sequential events inhibit the formation of the $80 \mathrm{~S}$ ribosome complex.

2005; Samuel et al., 2008; Murata et al., 2008), stomach (luminal compartment of the mucosa, isthmus/neck region, and fetal pyloric gland) (Nagata et al., 2006; Akasaka et al., 2005; Asai et al., 2005; Murata et al., 2008), breast (mammary gland epithelial cell) (Clarke et al., 2005), and hair follicles (kerationocyte) (Sugiyama-Nakagiri et al., 2006). These studies suggest that the Msi1 protein may be an effective marker for stem/progenitor cells in various tissues and acts as a regulator of the stem cell status of cells.

On the other hand, the function of the Msi2 protein in neural stem/progenitor cells is still unclear, though it is known that Msi1 and Msi2 have similar RNA-binding specificity 
(Sakakibara et al., 2001). The results of an Msi1 and Msi2 double knockout experiment suggested that these proteins have mutually complementary functions (Sakakibara et al., 2002).

Recently, the molecular mechanism of translational repression by Msi1 has been uncovered. Kawahara et al. identified the poly(A)-binding protein (PABP) as an Msi1-binding protein and found that Msi1 competes with elF4G for PABP binding on its target mRNAs (Fig.5) (Kawahara et al., 2008).

However, the molecular machinery of other functions of Musashi protein (described below) remains to be elucidated. A survey for the co-factors of Musashi proteins is an important future task in order to fully understand the functions of these proteins.

\section{Musashi-related diseases - Cancers and neural disorders}

Msi1 has been shown to play a role in a variety of cancers and neural disorders.

Several studies have reported high Msi1 protein expression in many types of tumors, including glioma (Toda et al., 2001), hepatoma (Shu et al., 2002), colorectal adenoma (Sakatani et al., 2005; Schulenburg et al., 2007), teratoid/rhabdoid tumors in eye (Fujita et al., 2005), non-small cell lung cancer (Kanai et al., 2006), retinoblastoma (Seigel et al., 2007), medulloblastoma (Nakano et al., 2007; Sanchez-Diaz et al., 2008), ependymoma (Nakano et al., 2007), endometrial carcinoma (Götte et al., 2008), neurocytoma (Yano et al., 2009), glioblastoma (Liu et al., 2006), and cervical carcinoma (Ye et al., 2008). This might because that many carcinoma cells are of epithelial stem cell lineage (Miller et al., 2005) which express the Msi1 protein.

Although the exact function of Msi1 in these cancer cells remains unclear, the knockdown of Msi1 via siRNA resulted in arrested tumor growth in colon adenocarcinoma xenografts transplanted in athymic nude mice, reduced cancer cell proliferation, and increased apoptosis (Sureban et al., 2008). These results suggest an important potential role for Msi1 in tumorigenesis and tumor proliferation.

It has also been shown that some tumors express the Msi2 protein in addition to Msi1 (Seigel et al., 2007). This may indicate a complementary role of the two proteins in tumors.

Msi1 is also hypothesized to be a key player in neuronal disorders. Several reports indicate that Msi1 is relevant to neurodegenerative disorders, such as Alzheimer's disease (AD). Ectopic expression of Msi1 was observed in the hippocampus of AD patients (Lovell \& Markesbery, 2005), while a significant decrease in Msi1-expressing cells was observed in the SVZ (Ziabreva et al., 2006). Although it is difficult to explain these phenomena at present, the function of Msi1 in maintaining the stemness of NSCs might play a role in the pathogenesis of the disease.

Msi1 may also play a role in Parkinson's disease (PD), an another type of neurodegenerative disorder. A clinical experiment found that chronic treatment with an anti-PD drug increased Msi1-positive cells in the SVZ of PD patients. The authors suggested that impaired neurogenesis may contribute to the decline in this neurodegenerative disease (O'Sullivan et al., 2011).

Oki et al. (2010) reported an up-regulation in Msi1 expression in collapsed nervous system tissue arising from a blood circulation defect. In the ischemic striatum induced by middle 
cerebral artery occlusion (MCAO), an increase in Msi1-immunoreactivity was observed in reactive astrocytes beginning at 2 days after $\mathrm{MCAO}$ and persisting until 14 days after MCAO. The proliferation of Msi1-positive cells was observed beginning at 4 days after MCAO and reached a peak at 7 days after MCAO (Oki et al., 2010)

Nakayama et al. (2010) also observed an induction of Msi1-positive cells at the site of ischemic lesions beginning on day 1 after stroke in humans. This result indicates the presence of a regional regenerative response in the human cerebral cortex and the importance of Msi1 in this phenomenon (Nakayama et al., 2010).

Interestingly, Msi1 protein-expressing cells are increased in the hippocampus of mesial temporal lobe epilepsy (MTLE) patients (Crespel et al., 2005). Large numbers of Msi1positive cells were also observed in the SVZ in these patients (Crespel et al., 2005). Increased neurogenesis has been reported in animal models of MTLE (Crespel et al., 2005). The abnormal proliferation of such Msi1-expressing neural progenitors in the hippocampus might cause epilepsy.

Unlike Msi1, the relevance of Msi2 to various diseases has not yet been elucidated. However, it was recently demonstrated that Msi2 triggers the acute transformation of chronic myelogenous leukaemia (CML) through translational control of the Numb protein in humans (Ito et al., 2010; Kharas et al., 2010; Nishimoto \& Okano, 2010). Byers et al. (2011) reported that Msi2 protein expression can be a clinical prognostic biomarker of human myeloid leukaemia (Byers et al., 2011)

\section{Novel finding for the functions of Musashi proteins}

Although Musashi proteins are thought to act as translational suppressors, MacNicol and co-workers found a novel function of Musashi in Xenopus oocytes. In this system, it activates the translation of mos mRNA (Charlesworth et al., 2006), a gene that is related to the meiotic cell cycle progression (Sagata et al., 1988). This is an opposite result from previous findings on the translational effect of Msi1. Interestingly, in human oocytes, a parallel physiological phenomenon is controlled by factors other than the Musashi homolog proteins (Prasad et al., 2008).

A similar translation-activating effect of Msi1 was also observed in mammals. Kuwako et al. (2010) found that the Msi1 protein up-regulates the translation of the Robo3 protein and controls midline crossing in precerebellar neurons. While previous studies reported that the Msi1-binding sites are in the 3'UTR of mRNAs, the Msi1-binding region in Robo3 mRNA is in the protein-coding region and does not bear the Msi1-binding consensus sequence (Kuwako et al., 2010). This result implies that the discovery of novel Msi1 co-factors will be an important task for understanding the molecular mechanism of the Msi1 proteins in translational control.

Until recently, only a small number of Msi1-targeted mRNAs (Imai et al., 2001; Battelli et al., 2006) had been reported. De Sousa Abreu et al. (2009) performed an RNA immnoprecipitation (RIP)-Chip assay in HEK293T cells, a cell line derived from human embryonic kidney, to comprehensively identify the target mRNAs (de Sousa Abreu, 2009). They identified a group of 64 mRNAs whose genes belong to two main functional categories pertinent to tumorigenesis and protein modification. A subsequent proteomics study also revealed that 
Msi1 can have not only negative but also positive effects on gene expression for some of the targets (de Sousa Abreu et al., 2009). This result is consistent with other recent findings.

Our group also performed in vitro screening analysis to detect specific binding targets of Msi1 controlling the stem cell status of NSCs. We succeeded in identifying a novel target mRNA of Msi1, doublecortin ( $d c x)$, from an mRNA library of embryonic mouse brain tissue (Horisawa et al., 2009).

The $d c x$ is a gene related to the migration of newborn neurons and neural development. Mutations in this gene cause an X-linked dominant disorder characterized by classic lissencephaly with severe mental retardation and epilepsy in hemizygous males and subcortical laminar heterotopia, also known as double cortex syndrome, associated with milder mental retardation and epilepsy in heterozygous females (Gleeson et al., 1998; des Portes et al., 1998; Sossey-Alaoui et al., 1998).

The Msi1 protein specifically bound to the 3'UTR region of the mRNA in vitro, which contains an Msi1 binding motif, and repressed translation of a reporter gene linked to the mRNA fragment (Horisawa et al., 2009).

We hypothesize that the Msi1 protein prevents inappropriate migration of NSCs through translational inhibition of the $d c x$ gene. Several findings support our hypothesis. First, the Dcx protein is expressed only in neuronal precursors just differentiated from NSCs (Couillard-Despres et al., 2005). Secondly, mutually exclusive protein expression of Msi1 and Dcx in human brains was observed (Crespel et al., 2005). Finally, a knock-out of the Musashi family genes reduced the number of neurospheres isolated from embryonic mouse brains, while the knock-down of $d c x$ prevented migration of the cells from neurospheres, leaving their structure intact (Ocbina et al., 2006).

\begin{tabular}{|c|c|c|c|c|}
\hline $\begin{array}{c}\text { Gene } \\
\text { symbols }\end{array}$ & $\begin{array}{l}\text { Functions of the } \\
\text { encoded proteins }\end{array}$ & Spices & Effects & References \\
\hline$t t k 69$ & Notch signaling & $\begin{array}{l}\text { Drosophila } \\
\text { melanogaster }\end{array}$ & $\begin{array}{l}\text { Translational } \\
\text { suppression }\end{array}$ & $\begin{array}{c}\text { Okabe et al, } \\
2001\end{array}$ \\
\hline$m-n u m b$ & Notch signaling & $\begin{array}{l}\text { Mus musculus } \\
\text { (Msi1) }\end{array}$ & $\begin{array}{l}\text { Translational } \\
\text { suppression }\end{array}$ & Imai et al, 2001 \\
\hline$p 21$ WAF1 & Cell cycle control & $\begin{array}{l}\text { Mus musculus } \\
\text { (Msi1) }\end{array}$ & $\begin{array}{l}\text { Translational } \\
\text { suppression }\end{array}$ & $\begin{array}{l}\text { Battelli et al, } \\
2006\end{array}$ \\
\hline mos & $\begin{array}{l}\text { Meiotic cell cycle } \\
\text { progression }\end{array}$ & $\begin{array}{l}\text { Xenopus laevis } \\
\text { (Msi1) }\end{array}$ & $\begin{array}{l}\text { Translational } \\
\text { activation }\end{array}$ & $\begin{array}{c}\text { Charlesworth et } \\
\text { al, } 2006\end{array}$ \\
\hline$d c x$ & Neural migration & $\begin{array}{l}\text { Mus musculus } \\
\text { (Msi1) }\end{array}$ & $\begin{array}{l}\text { Translational } \\
\text { suppression? }\end{array}$ & $\begin{array}{c}\text { Horisawa et al, } \\
2009\end{array}$ \\
\hline robo3 & Axonal guidance & $\begin{array}{l}\text { Mus musculus } \\
\text { (Msi1) }\end{array}$ & $\begin{array}{l}\text { Translational } \\
\text { activation }\end{array}$ & $\begin{array}{c}\text { Kuwako et al, } \\
2010\end{array}$ \\
\hline let-7 & Non coding RNA & $\begin{array}{l}\text { Mus musculus } \\
\text { (Msi1) }\end{array}$ & $\begin{array}{c}\text { Nuclear translocation } \\
\text { of Lin } 28\end{array}$ & $\begin{array}{c}\text { Kawahara et al, } \\
2010\end{array}$ \\
\hline numb & Notch signaling & $\begin{array}{l}\text { Homo sapiens } \\
\text { (Msi2) }\end{array}$ & $\begin{array}{l}\text { Translational } \\
\text { suppression }\end{array}$ & Ito et al, 2010 \\
\hline
\end{tabular}

Table 1. Known target RNAs of Musashi proteins 
In addition, we also identified another candidate Msi1-binding mRNA that is related to neuronal migration and axon outgrowth (unpublished data). Thus, Msi1 might repress the maturation of neural stem/progenitor cells to neurons through direct translational inhibition of the genes that influence neuronal maturation and migration.

All of the known target RNAs of Musashi proteins, which have been validated in previous studies, are listed in Table 1.

The precise mechanism through which the function of Msi1 is controlled remains unclear. Although Wang et al. (2008) proposed that the Msi1 protein is involved in both Notch and Wnt signaling pathways as a novel autocrine process (Nagata et al., 2006; Glazer et al., 2008), details of the mechanism remain unclear, and direct regulators of Msi1 have not been identified.

On the other hand, Ratti et al. (2006) reported post-transcriptional regulation of Msi1 mRNA by embryonic lethal abnormal vision (ELAV), an RNA-binding protein of Drosophila (Ratti et al., 2006). This is an interesting result because it may imply that some kind of cascade of post-transcriptional regulation contributes to neurogenesis, in addition to other machinery, i.e., signal transduction, transcriptional regulation, and post-translational modification.

Upstream mechanisms regulating Msi1 transcription have also been studied. Kawase et al. (2011) found that the sixth intron of the msi1 gene has a regulatory element for msi1 transcription in neural stem/progenitor cells. The identification of transcription factors for the msi1 gene will help elucidate the role of the Msi1 protein in stem cells (Kawase et al., 2011).

More recently, Kawahara et al. (2011) discovered a novel function of the Msi1 protein. They showed that Msi1 works in concert with Lin28 to regulate post-transcriptional microRNA (miRNA) biogenesis in the cropping step, which occurs in the nucleus. This indicates that Msi1 can influence stem cell maintenance and differentiation by controlling the subcellular localization of proteins involved in miRNA synthesis, as well as by regulating the translation of its target mRNA (Kawahara et al., 2011).

\section{Conclusion}

Somatic stem/precursor cells, including neural stem cells, are promising targets for regenerative medicine. Because these cells are derived from the patients themselves, they are not subject to the ethical questions and possible immunological rejection that are common problems in regenerative therapies using embryonic stem (ES) cell.

The Musashi family proteins are key factors for the understanding and application of somatic stem cells. Musashi proteins control the stem cell state through the translational regulation of target mRNAs, and the Musashi family is a highly conserved RNA-binding protein group expressed in undifferentiated stem/precursor cells at both embryonic and adult stages.

Although several studies have revealed that a Notch signal inhibitor, m-numb, and a cell cycle regulator, $p 21$ WAF1, are direct targets of Msi1, a mouse homolog of Musashi and that the machinery involved is located in the context of both the Notch and Wnt signaling pathways (Glazer et al., 2008), the full picture of Msi1 function in neural stem/precursor cells remains to be uncovered. Recently, de Sousa Abreu et al. employed an RNA immunoprecipitation (RIP)-chip technique to comprehensively detect Msi1 targeted mRNAs, and they identified a 
group of 64 mRNAs from HEK293T cells, whose genes belong to two main functional categories pertinent to tumorigenesis: 1) cell cycle, proliferation, differentiation, and apoptosis and 2) protein modification (de Sousa Abreu et al., 2009). However, a more specific survey is necessary to identify the key factors that regulate stemness. We speculate that Msi1 might have specific targets in each cell type or site, such as $d c x$, in addition to the previously discovered targets, which are related to the cell cycle, proliferation, and self-renewal.

While Musashi proteins were originally thought to act as translational suppressors, recent findings indicate that these proteins can activate the translation of specific targets (Charlesworth et al., 2006; de Sousa Abreu et al., 2009; Kuwako et al., 2010). This result indicates that currently unknown molecular machinery may exist that differs from the translational suppression machinery (Kawahara et al., 2008). Components of this machinery, e.g., binding proteins of Msi1, need to be comprehensively clarified using high-throughput techniques (Rigaut et al., 1999; Horisawa et al., 2004, 2008).

Many researches indicate that Musashi proteins have strong associations with some diseases, such as cancers and neuronal disorders. A more complete understanding of the Musashi proteins will also contribute to the development of therapies for these diseases.

\section{Acknowledgment}

We thank Dr. Takao Imai and Prof. Hideyuki Okano (Department of Physiology, Keio University School of Medicine) for valuable advice and discussion.

\section{References}

Akasaka, Y.; Saikawa, Y.; Fujita, K.; Kubota, T.; Ishikawa, Y.; Fujimoto, A.; Ishii, T.; Okano, H. \& Kitajima, M. (2005) Expression of a candidate marker for progenitor cells, Musashi-1, in the proliferative regions of human antrum and its decreased expression in intestinal metaplasia. Histopathology, Vol.47, No.4, (October 2005), pp.348-356, ISSN 1365-2559

Asai, R.; Okano, H. \& Yasugi, S. (2005) Correlation between Musashi-1 and c-hairy-1 expression and cell proliferation activity in the developing intestine and stomach of both chicken and mouse. Dev Growth Differ., Vol.47, No.8, (October 2005) pp.501510, ISSN 0012-1592

Battelli, C.; Nikopoulos, G.N.; Mitchell, J.G. \& Verdi, J.M. (2006) The RNA-binding protein Musashi-1 regulates neural development through the translational repression of p21WAF-1. Mol Cell Neurosci., Vol.31, No.1, (January 2006), pp.85-96, ISSN 1044-7431

Berdnik, D.; Török, T.; González-Gaitán, M. \& Knoblich, J.A. (2002) The endocytic protein alpha-Adaptin is required for numb-mediated asymmetric cell division in Drosophila. Dev Cell. Vol.3, No.2, (August 2002), pp.221-231, ISSN 1534-5807

Byers, R.J.; Currie, T.; Tholouli, E.; Rodig, S.J. \& Kutok, J.L. MSI2 protein expression predicts unfavorable outcome in acute myeloid leukemia. (2011) Blood, in press, (July 2011), ISSN 0006-4971

Charlesworth, A.; Wilczynska, A.; Thampi, P., Cox, L.L. \& MacNicol, A.M. (2006) Musashi regulates the temporal order of mRNA translation during Xenopus oocyte maturation. EMBO J., Vol.25, No.12, (June 2006), pp.2792-2801, ISSN 0261-4189 
Clarke, R.B.; Spence, K.; Anderson, E.; Howell, A.; Okano, H. \& Potten, C.S. (2005) A putative human breast stem cell population is enriched for steroid receptor-positive cells. Dev Biol., Vol.277, No.2, (January 2005), pp.443-456, ISSN 0012-1606

Couillard-Despres, S.; Winner, B.; Schaubeck, S.; Aigner, R.; Vroemen, M.; Weidner, N.; Bogdahn, U.; Winkler, J.; Kuhn, H.G. \& Aigner, L. (2005) Doublecortin expression levels in adult brain reflect neurogenesis. Eur J Neurosci., Vol.21, No.1, (January 2005), pp.1-14, ISSN 1460-9568

Crespel, A.; Rigau, V.; Coubes, P.; Rousset, M.C.; de Bock, F.; Okano, H.; Baldy-Moulinier, M.; Bockaert, J. \& Lerner-Natoli, M. (2005) Increased number of neural progenitors in human temporal lobe epilepsy. Neurobiol Dis., Vol.19, No.3, (Augut 2005), pp.436-450, ISSN 0969-9961

Cuadrado, A.; García-Ferníndez, L.F.; Imai, T.; Okano, H. \& Muñoz, A. (2002) Regulation of tau RNA maturation by thyroid hormone is mediated by the neural RNA-binding protein musashi-1. Mol Cell Neurosci., Vol.20, No.2, (June 2002), pp.198-210, ISSN 1044-7431

de Sousa Abreu, R.; Sanchez-Diaz, P.C.; Vogel, C.; Burns, S.C.; Ko, D.; Burton, T.L.; Vo, D.T.; Chennasamudaram, S.; Le, S.Y.; Shapiro, B.A. \& Penalva, L.O. (2009) Genomic analyses of musashi1 downstream targets show a strong association with cancerrelated processes. J Biol Chem., Vol.284, No.18, (May 2009), pp.12125-12135, ISSN 0021-9258

des Portes, V.; Pinard, J.M.; Billuart, P.; Vinet, M.C.; Koulakoff, A.; Carrié A.; Gelot, A.; Dupuis, E.; Motte, J.; Berwald-Netter, Y.; Catala, M.; Kahn, A.; Beldjord, C. \& Chelly, J. (1998) A novel CNS gene required for neuronal migration and involved in X-linked subcortical laminar heterotopia and lissencephaly syndrome. Cell, Vol.92, No.1, (January 1998), pp.51-61, ISSN 0092-8674

Fujita, M.; Sato, M.; Nakamura, M.; Kudo, K.; Nagasaka, T.; Mizuno, M.; Amano, E.; Okamoto, Y.; Hotta, Y.; Hatano, H.; Nakahara, N.; Wakabayashi, T. \& Yoshida J. (2005) Multicentric atypical teratoid/rhabdoid tumors occurring in the eye and fourth ventricle of an infant: case report. J Neurosurg., Vol.102, No.3, (April 2005), pp.299-302, ISSN 0022-3085

Glazer, R.I.; Wang, X.Y.; Yuan, H. \& Yin, Y. (2008) Musashi1: a stem cell marker no longer in search of a function. Cell Cycle, Vol.7, No.17, (September 2008) pp.2635-2639, ISSN 1538-4101

Gleeson, J.G.; Allen, K.M.; Fox, J.W.; Lamperti, E.D.; Berkovic, S.; Scheffer, I.; Cooper, E.C.; Dobyns, W.B.; Minnerath, S.R.; Ross, M.E. \& Walsh, C.A. (1998) Doublecortin, a brain-specific gene mutated in human $\mathrm{X}$-linked lissencephaly and double cortex syndrome, encodes a putative signaling protein. Cell, Vol.92, No.1, (January 1998), pp.63-72, ISSN 0092-8674

Glisovic, T.; Bachorik, J.L.; Yong, J. \& Dreyfuss, G. RNA-binding proteins and posttranscriptional gene regulation. (2008) FEBS Lett., Vol.582, No.14, (January 2008), pp.1977-1986, ISSN 0014-5793

Good, P.; Yoda, A.; Sakakibara, S.; Yamamoto, A.; Imai, T.; Sawa, H.; Ikeuchi, T.; Tsuji, S.; Satoh, H. \& Okano, H. (1998) The human Musashi homolog 1 (MSI1) gene encoding the homologue of Musashi/Nrp-1, a neural RNA-binding protein putatively expressed in CNS stem cells and neural progenitor cells. Genomics, Vol.52, No.3, (September 1998), pp.382-384, ISSN 0888-7543 
Götte, M.; Wolf, M.; Staebler, A.; Buchweitz, O.; Kelsch, R.; Schüring, A.N. Kiesel, L. (2008) Increased expression of the adult stem cell marker Musashi-1 in endometriosis and endometrial carcinoma. J Pathol., Vol.215, No.3, (July 2008), pp.317-329, ISSN 10969896

Higuchi, S.; Hayashi, T.; Tarui, H.; Nishimura, O.; Nishimura, K.; Shibata, N.; Sakamoto, H. \& Agata, K. (2008) Expression and functional analysis of musashi-like genes in planarian CNS regeneration. Mech Dev., Vol.125, No.7, (July 2008), pp.631-645, ISSN 0047-6374

Hirota, Y.; Okabe, M.; Imai, T.; Kurusu, M.; Yamamoto, A.; Miyao, S.; Nakamura, M.; Sawamoto, K. \& Okano, H. (1999) Musashi and seven in absentia downregulate Tramtrack through distinct mechanisms in Drosophila eye development. Mech Dev., Vol.87, No.1-2, (September 1999), pp.93-101, ISSN 0047-6374

Hitoshi, S.; Alexson, T.; Tropepe, V.; Donoviel, D.; Elia, A.J.; Nye, J.S.; Conlon, R.A.; Mak, T.W.; Bernstein, A. \& van der Kooy, D. (2002) Notch pathway molecules are essential for the maintenance, but not the generation, of mammalian neural stem cells. Genes Dev., Vol.16, No.7, (April 2002), pp.846-858, ISSN 0890-9369

Horisawa, K.; Tateyama, S.; Ishizaka, M.; Matsumura, N.; Takashima, H.; Miyamoto-Sato, E.; Doi, N. \& Yanagawa, H. (2004) In vitro selection of Jun-associated proteins using mRNA display. Nucleic Acids Res., Vol.32, No.21, (December 2004), e169, ISSN 03051048

Horisawa, K.; Doi, N. \& Yanagawa, H. (2008) Use of cDNA tiling arrays for identifying protein interactions selected by in vitro display technologies. PLoS One, Vol.3, No.2, (February 2008), e1646, ISSN 1932-6203

Horisawa, K.; Imai, T.; Okano, H. \& Yanagawa, H. (2009) 3'-Untranslated region of doublecortin mRNA is a binding target of the Musashi1 RNA-binding protein. FEBS Lett., Vol.583, No.14, (July 2009), pp.2429-2434, ISSN 0014-5793

Imai, T.; Tokunaga, A.; Yoshida, T.; Hashimoto, M.; Mikoshiba, K.; Weinmaster, G.; Nakafuku, M. \& Okano, H. (2001) The neural RNA-binding protein Musashi1 translationally regulates mammalian numb gene expression by interacting with its mRNA. Mol Cell Biol., Vol.21, No.12, (June 2001), pp.3888-3900, ISSN 0270-7306

Ito, K. \& Hotta, Y. (1992) Proliferation pattern of postembryonic neuroblasts in the brain of Drosophila melanogaster. Dev Biol., Vol.149, No.1 (January 1992), pp.134-148, ISSN 0012-1606

Ito, T.; Kwon, H.Y.; Zimdahl, B.; Congdon, K.L.; Blum, J.; Lento, W.E.; Zhao, C.; Lagoo, A.; Gerrard, G.; Foroni, L.; Goldman, J.; Goh, H.; Kim, S.H.; Kim, D.W.; Chuah, C.; Oehler, V.G.; Radich, J.P.; Jordan, C.T. \& Reya, T. (2010) Regulation of myeloid leukaemia by the cell-fate determinant Musashi. Nature, Vol.466, No,7307, (August 2010), pp.765-768, ISSN 0028-0836

Kanai, R.; Eguchi, K.; Takahashi, M.; Goldman, S.; Okano, H.; Kawase, T. \& Yazaki, T. (2006) Enhanced therapeutic efficacy of oncolytic herpes vector G207 against human nonsmall cell lung cancer--expression of an RNA-binding protein, Musashi1, as a marker for the tailored gene therapy. J Gene Med., Vol.8, No.11, (November 2006), pp.1329-1340, ISSN 1099-498X

Kaneko, Y.; Sakakibara, S.; Imai, T.; Suzuki, A.; Nakamura, Y.; Sawamoto, K.; Ogawa, Y.; Toyama, Y.; Miyata, T. \& Okano, H. (2000) Musashi1: an evolutionally conserved marker for CNS progenitor cells including neural stem cells. Dev Neurosci., Vol.22, No.1-2, pp.139-153, ISSN 0378-5866 
Kawahara, H.; Imai, T.; Imataka, H.; Tsujimoto, M.; Matsumoto, K. \& Okano, H. (2008) Neural RNA-binding protein Musashi1 inhibits translation initiation by competing with eIF4G for PABP. J Cell Biol., Vol.181, No.4, (May 2008), pp.639-653, ISSN 0021-9525

Kawahara, H.; Okada, Y.; Imai, T.; Iwanami, A.; Mischel, P.S. \& Okano, H. (2011) Musashi1 cooperates in abnormal cell lineage protein 28 (Lin28)-mediated let-7 family microRNA biogenesis in early neural differentiation. J Biol Chem., Vol.286, No.18, (May 2011), pp.16121-16130, ISSN 0021-9258

Kawase, S.; Imai, T.; Miyauchi-Hara, C.; Yaguchi, K.; Nishimoto, Y.; Fukami, S.; Matsuzaki, Y.; Miyawaki, A.; Itohara, S. \& Okano H. (2011) Identification of a novel intronic enhancer responsible for the transcriptional regulation of musashi1 in neural stem/ progenitor cells. Mol Brain, Vol.4, (April 2011), 14, ISSN 1756-6606

Kawashima, T.; Murakami, A.R.; Ogasawara, M.; Tanaka, K.; Isoda, R.; Sasakura, Y.; Nishikata, T.; Okano, H. \& Makabe, K.W. (2000) Expression patterns of musashi homologs of the ascidians, Halocynthia roretzi and Ciona intestinalis. Dev Genes Evol., Vol.210, No.3, (March 2000), pp.162-165, ISSN 0949-944X

Kayahara, T.; Sawada, M.; Takaishi, S.; Fukui, H.; Seno, H.; Fukuzawa, H.; Suzuki, K.; Hiai, H.; Kageyama, R.; Okano, H. \& Chiba, T. (2003) Candidate markers for stem and early progenitor cells, Musashi-1 and Hes1, are expressed in crypt base columnar cells of mouse small intestine. FEBS Lett., Vol.535, No.1-3, (January 2003), pp.131135, ISSN 0014-5793

Keene, J.D. (2007) RNA regulons: coordination of post-transcriptional events. Nat Rev Genet., Vol.8, No.7, (July 2007), pp.533-543, ISSN 1471-0056

Kharas, M.G.; Lengner, C.J.; Al-Shahrour, F.; Bullinger, L.; Ball, B.; Zaidi, S.; Morgan, K.; Tam, W.; Paktinat, M.; Okabe, R.; Gozo, M.; Einhorn, W.; Lane, S.W.; Scholl, C.; Fröhling, S.; Fleming, M.; Ebert, B.L.; Gilliland, D.G.; Jaenisch, R. \& Daley, G.Q. Musashi-2 regulates normal hematopoiesis and promotes aggressive myeloid leukemia. (2010) Nat. Med., Vol. 16, No.8, (August 2010), pp.903-908, ISSN 1078-8956

Kobayashi, T.; Mizuno. H.; Imayoshi, I.; Furusawa, C.; Shirahige, K. \& Kageyama, R. (2009) The cyclic gene Hes1 contributes to diverse differentiation responses of embryonic stem cells. Genes Dev., Vol.23, No.16, (August 2009), pp.1870-1875, ISSN 0890-9369

Lai, Z.C. \& Li, Y. (1999) Tramtrack69 is positively and autonomously required for Drosophila photoreceptor development. Genetics, Vol.152, No.1, (May 1999), pp.299-305, ISSN 0016-6731

Liu, G.; Yuan, X.; Zeng, Z.; Tunici, P.; Ng, H.; Abdulkadir, I.R.; Lu, L.; Irvin, D.; Black, K.L. \& $\mathrm{Yu}$ J.S. (2006) Analysis of gene expression and chemoresistance of CD133+ cancer stem cells in glioblastoma. Mol Cancer, Vol.5, (December 2006), 67, ISSN 1476-4598

Lovell, M.A. \& Markesbery, W.R. (2005) Ectopic expression of Musashi-1 in Alzheimer disease and Pick disease. J Neuropathol Exp Neurol., Vol.64, No.8, (August 2005), pp.675-680, ISSN 0022-3069

Lowe, C.J.; Wu, M.; Salic, A.; Evans, L.; Lander, E.; Stange-Thomann, N.; Gruber, C.E.; Gerhart, J. \& Kirschner, M. (2003) Anteroposterior patterning in hemichordates and the origins of the chordate nervous system. Cell, Vol.113, No.7, (June 2003), pp.853865, ISSN 0092-8674

Miller, S.J.; Lavker, R.M. \& Sun, T.T. (2005) Interpreting epithelial cancer biology in the context of stem cells: tumor properties and therapeutic implications. Biochim Biophys Acta., Vol.1756, No.1, (September 2005), pp.25-52, ISSN 0006-3002 
Miyanoiri, Y.; Kobayashi, H.; Imai, T.; Watanabe, M.; Nagata, T.; Uesugi, S.; Okano, H. and Katahira, M. (2003) Origin of higher affinity to RNA of the N-terminal RNAbinding domain than that of the C-terminal one of a mouse neural protein, musashi1, as revealed by comparison of their structures, modes of interaction, surface electrostatic potentials, and backbone dynamics. J Biol Chem., Vol.278 No. 42, (October 2003), pp.41309-41315, ISSN 0021-9258

Murata, H.; Tsuji, S.; Tsujii, M.; Nakamura, T.; Fu, H.Y.; Eguchi, H.; Asahi, K.; Okano, H.; Kawano, S. \& Hayashi, N. (2008) Helicobacter pylori infection induces candidate stem cell marker Musashi-1 in the human gastric epithelium. Dig Dis Sci., Vol.53, No,2, (February 2008), pp.363-369, ISSN 0163-2116

Murayama, M.; Okamoto, R.; Tsuchiya, K.; Akiyama, J.; Nakamura, T.; Sakamoto, N.; Kanai, T. \& Watanabe, M. (2009) Musashi-1 suppresses expression of Paneth cell-specific genes in human intestinal epithelial cells. J Gastroenterol., Vol.44, No.3, (February 2009), pp.173-182, ISSN 0002-9270

Nagata, H.; Akiba, Y.; Suzuki, H.; Okano, H. and Hibi, T. (2006) Expression of Musashi-1 in the rat stomach and changes during mucosal injury and restitution. FEBS Lett., Vol.580, No.1, (January 2006), pp.27-33, ISSN 0014-5793

Nagata, T.; Kanno, R.; Kurihara, Y.; Uesugi, S.; Imai, T.; Sakakibara, S.; Okano, H. and Katahira, M. (1999) Structure, backbone dynamics and interactions with RNA of the C-terminal RNA-binding domain of a mouse neural RNA-binding protein, Musashi1. J Mol Biol., Vol.287, No.2, (March 1999), pp.315-330, ISSN 0022-2836

Nakamura, M.; Okano, H.; Blendy, J.A. and Montell, C. (1994) Musashi, a neural RNAbinding protein required for Drosophila adult external sensory organ development. Neuron,Vol.13, No.1, (July 1994), pp.67-81, ISSN 0896-6273

Nakamura, Y.; Sakakibara, S.; Miyata, T.; Ogawa, M.; Shimazaki, T.; Weiss, S.; Kageyama, R. \& Okano, H. (2000) The bHLH gene hes1 as a repressor of the neuronal commitment of CNS stem cells. J Neurosci., Vol.20, No.1, (January 2000), pp.283-293, ISSN 0270-6474

Nakano, A.; Kanemura, Y.; Mori, K.; Kodama, E.; Yamamoto, A.; Sakamoto, H.; Nakamura, Y.; Okano, H.; Yamasaki, M. and Arita, N. (2007) Expression of the neural RNAbinding protein Musashi1 in pediatric brain tumors. Pediatr Neurosurg., Vol.43, No.4, pp.279-284, ISSN 8755-6863

Nakayama, D.; Matsuyama, T.; Ishibashi-Ueda, H.; Nakagomi, T.; Kasahara, Y.; Hirose, H; Kikuchi-Taura, A.; Stern, D.M.; Mori, H. \& Taguchi, A. Injury-induced neural stem/progenitor cells in post-stroke human cerebral cortex. (2010) Eur J Neurosci., Vol.31, No.1, (January 2010), pp.90-98, ISSN 0953-816X

Nikpour, P.; Baygi, M.E.; Steinhoff, C.; Hader, C.; Luca, A.C.; Mowla, S.J. \& Schulz, W.A. (2011) The RNA binding protein Musashi1 regulates apoptosis, gene expression and stress granule formation in urothelial carcinoma cells. J Cell Mol Med., Vol.15, No.5, (May 2011), pp.1210-1224, ISSN 1582-1838

Nishimoto, Y. and Okano, H. New insight into cancer therapeutics: induction of differentiation by regulating the Musashi/Numb/Notch pathway. (2010) Cell Res., Vol.20, No.10, (October 2010), pp.1083-1085, ISSN 1001-0602

Nishimura, S.; Wakabayashi, N.; Toyoda, K.; Kashima, K. \& Mitsufuji, S. (2003) Expression of Musashi-1 in human normal colon crypt cells: a possible stem cell marker of 
human colon epithelium. Dig Dis Sci., Vol.48, No.8, (August 2003), pp.1523-1529, ISSN 0163-2116

Ocbina, P.J.; Dizon, M.L.; Shin, L. \& Szele, F.G. (2006) Doublecortin is necessary for the migration of adult subventricular zone cells from neurospheres. Mol. Cell Neurosci., Vol.33, No.2, (October 2006), pp.126-135, ISSN 1044-7431

Okabe, M.; Imai, T.; Kurusu, M.; Hiromi, Y. \& Okano, H. (2001) Translational repression determines a neuronal potential in Drosophila asymmetric cell division. Nature, Vol.411, No.6833, (May 2001), pp.94-98, ISSN 0028-0836

Okano, H.; Imai, T. \& Okabe, M. (2002) Musashi: a translational regulator of cell fate. J Cell Sci., Vol.115, Pt7, (April 2002), pp.1355-1359, ISSN 0021-9533

Okano, H.; Kawahara, H.; Toriya, M.; Nakao, K.; Shibata, S. \& Imai, T. (2005) Function of RNA-binding protein Musashi-1 in stem cells. Exp Cell Res., Vol.306, No.2, (June 2005), pp.349-356, ISSN 0014-4827

Oki, K.; Kaneko, N.; Kanki, H.; Imai, T.; Suzuki, N.; Sawamoto, K. \& Okano, H. (2010) Musashi1 as a marker of reactive astrocytes after transient focal brain ischemia. Neurosci Res., Vol.66, No.4, (April 2010), pp.390-395, ISSN 0168-0102

O'Sullivan, S.S.; Johnson, M.; Williams, D.R.; Revesz, T.; Holton, J.L.; Lees, A.J. \& Perry, E.K. (2011) The effect of drug treatment on neurogenesis in Parkinson's disease. Mov Disord., Vol.26, No.1, (January 2011), pp.45-50, ISSN 0885-3185

Pincus, D.W.; Keyoung, H.M.; Harrison-Restelli, C.; Goodman, R.R.; Fraser, R.A.; Edgar, M.; Sakakibara, S.; Okano, H.; Nedergaard, M. \& Goldman, S.A. (1998) Fibroblast growth factor-2/brain-derived neurotrophic factor-associated maturation of new neurons generated from adult human subependymal cells. Ann Neurol., Vol.43, No.5, (May 1998), pp.576-585, ISSN 0364-5134

Potten, C.S.; Booth, C.; Tudor, G.L.; Booth, D.; Brady, G.; Hurley, P.; Ashton, G.; Clarke, R.; Sakakibara, S. \& Okano, H. (2003) Identification of a putative intestinal stem cell and early lineage marker; musashi-1. Differentiation, Vol.71, No.1, (January 2003), pp.28-41, ISSN 0301-4681

Prasad, C.K.; Mahadevan, M.; MacNicol, M.C. \& MacNicol, A.M. (2008) Mos 3' UTR regulatory differences underlie species-specific temporal patterns of Mos mRNA cytoplasmic polyadenylation and translational recruitment during oocyte maturation. Mol Reprod Dev., Vol.75, No.8, (August 2008), pp.1258-1268, ISSN 1040-452X

Raji, B.; Dansault, A.; Leemput, J.; de la Houssaye, G.; Vieira, V.; Kobetz, A.; Arbogast, L.; Masson, C.; Menasche, M. \& Abitbol, M. (2007) The RNA-binding protein Musashi1 is produced in the developing and adult mouse eye. Mol Vis., Vol.13, (August 2007), pp.1412-1427, ISSN 1090-0535

Ratti, A.; Fallini, C.; Cova, L.; Fantozzi, R.; Calzarossa, C.; Zennaro, E.; Pascale, A.; Quattrone, A. and Silani, V. (2006) A role for the ELAV RNA-binding proteins in neural stem cells: stabilization of Msi1 mRNA. J Cell Sci., Vol.119, Pt7, (April 2006), pp.1442-1452, ISSN 0021-9533

Rigaut, G.; Shevchenko, A.; Rutz, B.; Wilm, M.; Mann, M. \& Séraphin, B. (1999) A generic protein purification method for protein complex characterization and proteome exploration. Nat Biotechnol., Vol.17, No.10, (October 1999), pp.1030-1032, ISSN 10870156 
Sagata, N.; Oskarsson, M.; Copeland, T.; Brumbaugh, J. and Vande Woude, G.F. (1988) Function of c-mos proto-oncogene product in meiotic maturation in Xenopus oocytes. Nature, Vol.335, No.6190, (October 1988), pp.519-525, ISSN 0028-0836

Sakakibara, S.; Imai, T.; Hamaguchi, K.; Okabe, M.; Aruga, J.; Nakajima, K.; Yasutomi, D.; Nagata, T.; Kurihara, Y.; Uesugi, S.; Miyata, T.; Ogawa, M.; Mikoshiba, K. \& Okano, H. (1996) Mouse-Musashi-1, a neural RNA-binding protein highly enriched in the mammalian CNS stem cell. Dev Biol., Vol.176, No.2, (June 1996), pp.230-242, ISSN 0012-1606

Sakakibara, S. \& Okano, H. (1997) Expression of neural RNA-binding proteins in the postnatal CNS: implications of their roles in neuronal and glial cell development. $J$ Neurosci., Vol.17, No.21, (November 1997), pp.8300-8312, ISSN 0270-6474

Sakakibara, S.; Nakamura, Y.; Satoh, H. \& Okano, H. (2001) RNA-binding protein Musashi2: developmentally regulated expression in neural precursor cells and subpopulations of neurons in mammalian CNS. J Neurosci., Vol.21, No.20, (October 2001), pp.80918107, ISSN 0270-6474

Sakakibara, S.; Nakamura, Y.; Yoshida, T.; Shibata, S.; Koike, M.; Takano, H.; Ueda, S.; Uchiyama, Y.; Noda, T. \& Okano, H. (2002) RNA-binding protein Musashi family: roles for CNS stem cells and a subpopulation of ependymal cells revealed by targeted disruption and antisense ablation. Proc Natl Acad Sci USA, Vol.99, No.23, (November 2002), pp.15194-15199, ISSN 0027-8424

Sakatani, T.; Kaneda, A.; Iacobuzio-Donahue, C.A.; Carter, M.G.; de Boom Witzel, S.; Okano, H.; Ko, M.S.; Ohlsson, R.; Longo, D.L. \& Feinberg, A.P. (2005) Loss of imprinting of Igf2 alters intestinal maturation and tumorigenesis in mice. Science, Vol.307, No.5717, (March 2005), pp.1976-1978, ISSN 0036-8075

Samuel, S.; Walsh, R.; Webb, J.; Robins, A.; Potten, C. \& Mahida, Y.R. (2009) Characterization of putative stem cells in isolated human colonic crypt epithelial cells and their interactions with myofibroblasts. Am J Physiol Cell Physiol., Vol.296, No.2, (February 2009), pp.C296-305, ISSN 0363-6143

Sanchez-Diaz, P.C.; Burton, T.L.; Burns, S.C.; Hung, J.Y. \& Penalva, L.O. (2008) Musashi1 modulates cell proliferation genes in the medulloblastoma cell line Daoy. BMC Cancer, Vol.8, (September 2008), 280, ISSN 1471-2407

Schulenburg, A.; Cech, P.; Herbacek, I.; Marian, B.; Wrba, F.; Valent, P. Ulrich-Pur, H. (2007) CD44-positive colorectal adenoma cells express the potential stem cell markers musashi antigen (msi1) and ephrin B2 receptor (EphB2). J Pathol., Vol.213, No.2, (October 2007), pp.152-160, ISSN 1096-9896

Seigel, G.M.; Hackam, A.S.; Ganguly, A.; Mandell, L.M. \& Gonzalez-Fernandez, F. (2007) Human embryonic and neuronal stem cell markers in retinoblastoma. Mol Vis. Vol.13, (June 2007), pp.823-832, ISSN 1090-0535

Shu, H.J.; Saito, T.; Watanabe, H.; Ito, J.I.; Takeda, H.; Okano, H. \& Kawata, S. (2002) Expression of the Musashi1 gene encoding the RNA-binding protein in human hepatoma cell lines. Biochem Biophys Res Commun., Vol.293, No.1, (April 2002), pp.150-154, ISSN 0006-291X

Sossey-Alaoui, K.; Hartung, A.J.; Guerrini, R.; Manchester, D.K.; Posar, A.; Puche-Mira, A.; Andermann, E.; Dobyns, W.B. \& Srivastava, A.K. (1998) Human doublecortin (DCX) and the homologous gene in mouse encode a putative $\mathrm{Ca}^{+}$-dependent 
signaling protein which is mutated in human X-linked neuronal migration defects. Hum Mol Genet., Vol.7, No.8, (August 1998), pp.1327-1332, ISSN 0964-6906

Sugiyama-Nakagiri, Y.; Akiyama, M.; Shibata, S.; Okano, H. \& Shimizu, H. (2006) Expression of RNA-binding protein Musashi in hair follicle development and hair cycle progression. Am J Pathol., Vol.168, No.1, (January 2006), pp.80-92, ISSN 0887-8005

Sureban, S.M.; May, R.; George, R.J.; Dieckgraefe, B.K.; McLeod, H.L.; Ramalingam, S.; Bishnupuri, K.S.; Natarajan, G.; Anant, S. \& Houchen, C.W. (2008) Knockdown of RNA binding protein musashi-1 leads to tumor regression in vivo. Gastroenterology, Vol.134, No.5, (May 2008), pp.1448-1458, ISSN 0016-5085

Susaki, K.; Kaneko, J.; Yamano, Y.; Nakamura, K.; Inami, W.; Yoshikawa, T.; Ozawa, Y.; Shibata, S.; Matsuzaki, O.; Okano, H. \& Chiba, C. (2009) Musashi-1, an RNAbinding protein, is indispensable for survival of photoreceptors. Exp Eye Res., Vol.88, No.3, (March 2009), pp.347-355, ISSN 0014-4835

Toda, M.; Iizuka, Y.; Yu, W.; Imai, T.; Ikeda, E.; Yoshida, K.; Kawase, T.; Kawakami, Y.; Okano, H. \& Uyemura, K. (2001) Expression of the neural RNA-binding protein Musashi1 in human gliomas. Glia, Vol.34, No.1, (April 2001), pp.1-7, ISSN 1098-1136

Tokunaga, A.; Kohyama, J.; Yoshida, T.; Nakao, K.; Sawamoto, K. \& Okano, H. (2004) Mapping spatio-temporal activation of Notch signaling during neurogenesis and gliogenesis in the developing mouse brain. J Neurochem., Vol.90, No.1, (July 2004), pp.142-154, ISSN 0022-3042

Tuerk, C. \& Gold, L. (1990) Systematic evolution of ligands by exponential enrichment: RNA ligands to bacteriophage T4 DNA polymerase. Science, Vol.249, No.4968, (August 1990), pp.505-510, ISSN 0036-8075

Wang, X.Y.; Yin, Y.; Yuan, H.; Sakamaki, T.; Okano, H. \& Glazer, R.I. (2008) Musashi1 modulates mammary progenitor cell expansion through proliferin-mediated activation of the Wnt and Notch pathways. Mol Cell Biol., Vol.28, No.11, (June 2008), pp.3589-3599, ISSN 0270-7306

Yano, H.; Ohe, N.; Shinoda, J.; Yoshimura, S. \& Iwama, T. (2009) Immunohistochemical study concerning the origin of neurocytoma--a case report. Pathol Oncol Res., Vol.15, No.2, (June 2009), pp.301-305, ISSN 1219-4956

Ye, F.; Zhou, C.; Cheng, Q.; Shen, J. and Chen, H. (2008) Stem-cell-abundant proteins Nanog, Nucleostemin and Musashi1 are highly expressed in malignant cervical epithelial cells. BMC Cancer, Vol.8, (April 2008), 108, ISSN 1471-2407

Yoda, A.; Sawa, H. \& Okano, H. (2000) MSI-1, a neural RNA-binding protein, is involved in male mating behaviour in Caenorhabditis elegans. Genes Cells. Vol.5, No.11, (November 2000), pp.885-895, ISSN 1356-9597

Yokota, N.; Mainprize, T.G.; Taylor, M.D.; Kohata, T.; Loreto, M.; Ueda, S.; Dura, W.; Grajkowska, W.; Kuo, J.S. \& Rutka, J.T. (2004) Identification of differentially expressed and developmentally regulated genes in medulloblastoma using suppression subtraction hybridization. Oncogene, Vol.23, No.19, (April 2004), pp.3444-3453, ISSN 0950-9232

Zhong, W.; Feder, J.N.; Jiang, M.M.; Jan, L.Y. \& Jan, Y.N. (1996) Asymmetric localization of a mammalian numb homolog during mouse cortical neurogenesis. Neuron, Vol.17, No.1, (July 1996), pp.43-53, ISSN 0896-6273

Ziabreva, I.; Perry, E.; Perry, R.; Minger, S.L.; Ekonomou, A.; Przyborski, S. \& Ballard, C. (2006) Altered neurogenesis in Alzheimer's disease. J Psychosom Res., Vol.61, No.3, (September 2006), pp.311-316, ISSN 0022-3999 


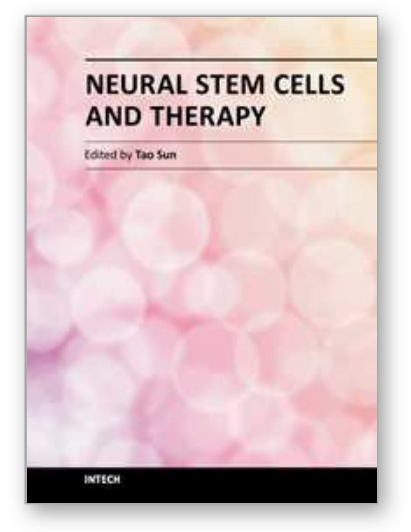

\author{
Neural Stem Cells and Therapy \\ Edited by Dr. Tao Sun
}

ISBN 978-953-307-958-5

Hard cover, 440 pages

Publisher InTech

Published online 15, February, 2012

Published in print edition February, 2012

This book is a collective work of international experts in the neural stem cell field. The book incorporates the characterization of embryonic and adult neural stem cells in both invertebrates and vertebrates. It highlights the history and the most advanced discoveries in neural stem cells, and summarizes the mechanisms of neural stem cell development. In particular, this book provides strategies and discusses the challenges of utilizing neural stem cells for therapy of neurological disorders and brain and spinal cord injuries. It is suitable for general readers, students, doctors and researchers who are interested in understanding the principles of and new discoveries in neural stem cells and therapy.

\title{
How to reference
}

In order to correctly reference this scholarly work, feel free to copy and paste the following:

Kenichi Horisawa and Hiroshi Yanagawa (2012). Musashi Proteins in Neural Stem/Progenitor Cells, Neural Stem Cells and Therapy, Dr. Tao Sun (Ed.), ISBN: 978-953-307-958-5, InTech, Available from:

http://www.intechopen.com/books/neural-stem-cells-and-therapy/musashi-proteins-in-neural-stem-progenitorcells

\section{INTECH}

open science | open minds

\section{InTech Europe}

University Campus STeP Ri

Slavka Krautzeka 83/A

51000 Rijeka, Croatia

Phone: +385 (51) 770447

Fax: +385 (51) 686166

www.intechopen.com

\section{InTech China}

Unit 405, Office Block, Hotel Equatorial Shanghai

No.65, Yan An Road (West), Shanghai, 200040, China

中国上海市延安西路65号上海国际贵都大饭店办公楼 405 单元

Phone: +86-21-62489820

Fax: $+86-21-62489821$ 
(C) 2012 The Author(s). Licensee IntechOpen. This is an open access article distributed under the terms of the Creative Commons Attribution 3.0 License, which permits unrestricted use, distribution, and reproduction in any medium, provided the original work is properly cited. 